functional DNA", and describe the various steps used to cleave viral or circular plasmid DNA, insert a separate DNA fragment, and grow up and separate unicellular organisms containing the altered DNA.

Still awaited is a decision from the Patent and Trademark Office on a second application made by the two universities on behalf of Dr Cohen and Dr Boyer, which covers any organism produced with the techniques covered in the first patent.

Mr Reimers said last week that, from the universities' point of view, this was likely to be the more important patent, since without its protection companies could manufacture products abroad using the recombinant DNA techniques, and subsequently sell them in the United States without having to pay royalties.

The Patent Office's decision on the second application is expected within a year. All such patent applications covering microorganisms had previously been held up pending a ruling from the Supreme Court, which decided in the summer that there is nothing in existing patent law which denies microorganisms protection.

Meanwhile, the University of California has filed a suit against the pharmaceutical company Hoffman LaRoche and the San Francisco firm Genentech, claiming that the two companies must pay damages to the university for the use of a cell line produced by university scientists which the companies have been developing as a potential commercial source of interferon.

The scientists at the University of California, Los Angeles who produced the cell line claim that it was passed to Hoffman LaRoche without their permission. But in the counter-claim Hoffman LaRoche is arguing that there were no conditions attached to the cell line when it was obtained indirectly through a researcher at the National Cancer Institute, and that the company therefore has no obligation to the university.

David Dickson

\section{Genetic engineering}

\section{Hormone growth}

Genentech, the California-based biotechnology company, will begin clinical trials of its latest genetically-engineered product, human growth hormone (HGH), in London this January. But Genentech's industrial partners in the venture, Kabi Vitrum AG of Sweden, are somewhat ambivalent about the development.

Kabi Vitrum is the major world producer of $\mathrm{HGH}$, made at present from cadaver pituitaries. The hormone is used to treat HGH-deficient children, reckoned to be some 7-10 per million of population. But the nature of the source naturally limits production, and Kabi estimates the true market to be three times the present supply; so the firm searched for other sources. Genetic engineering was an obvious possibility, as $\mathrm{HGH}$ is a small peptide, about the size of insulin.

So in $1978 \mathrm{Kabi}$ asked Genentech to produce a strain of Escherichia coli containing the $\mathrm{HGH}$ gene. Under the contract, Kabi would have sole world production rights, except in the United States and Canada, where they would be shared with Genentech. But Genentech was successful sooner than Kabi expected, and further surprised the firm by making rapid preparations for commercial production. Genentech had been expected to stick to research.

Now Genentech is well ahead with pilot tests in 700-litre fermenters, while Kabi has been restricted to 10 litres by Swedish limits on scale-up of genetic engineering experiments; and Genentech plans clinical trials at Great Ormond Street Hospital for Sick Children starting in January 1981. $\mathrm{Kabi}$, meanwhile, would wish to be more cautious. "We do not know about Genentech's toxicological testing", said Dr Bengt Karlsson, Kabi's managing director, "but we would not wish to put the product on clinical trial for at least six months". Nor is Kabi's caution due to lack of material, for they have access to Genentech's supply.

However, in London, where Dr James Tanner at Great Ormond Street will conduct the trial, it is felt that Genentech's toxicity testing has been quite sufficient. There have been plenty of animal and monkey tests, says Dr Tanner, and the UK Department of Health has passed the material for clinical trials. The Genentech $\mathrm{HGH}$ will be given to 20 patients for a year, 10 of them first treatments, and the other 10 already three years into a course of pituitary $\mathrm{HGH}$. The main contaminant will be 1-2 per cent of bacterial protein; and the danger is that $\mathrm{HGH}$-like proteins in this material may induce antibody formation to true HGH.

Dr Tanner welcomes the new source of the hormone. In the United Kingdom there are 100 new cases a year of $\mathrm{HGH}$ deficiency, and just enough pituitary $\mathrm{HGH}$ to go round (produced from 60,000 cadavers a year). But it is always "touch and go" each year whether sufficient cadavers will be made available. Moreover, if there were more $\mathrm{HGH}$ around, it could be tried out on more marginal cases of delayed growth, or slow bone healing after fractures.

Ultimately, Genentech will not be the source of $\mathrm{HGH}$ in Britain. Kabi announced last week that it has concluded a deal with the Department of Health for the Centre for Applied Microbiological Research at Porton Down to conduct scale-up trials on the Genentech bacterium. In exchange, Kabi will offer the product at a preferential price to the Department of Health, and assist Porton with its present production of $\mathrm{HGH}$ from pituitaries. (Kabi believes it has a more efficient extraction system.)

The centre is seeking permission from the Genetic Manipulation Advisory Group to ferment the engineered $E$. coli in
400 -litre vats; and to satisfy GMAG, it must show that the organism is killed in the closed fermenter before the material is extracted.

Despite early misgivings, the Department of Health has begun to encourage Porton to become involved with industrial applications of the recombinant DNA technique - Unfortunately nothing has yet come forward in the United Kingdom that fits the bill. Dr Peter Sutton, director of Porton, is delighted at the deal with Kabi: "It means we can get our feet wet" with commercial scale genetic engineering, he said last week.

Robert Walgate

\section{US Administration}

\section{Reagan's men?}

\section{Washington}

President-elect Ronald Reagan's transition staff is sifting through the list of candidates for top-level positions in the new Administration, and the names of the first cabinet appointments should be announced this week. Potential choices have been widely discussed in the press often names intentionally leaked to gauge public reaction - so few major surprises are expected.

Top candidate for the renamed Department of Health and Human Services (DHHS), responsible for the biomedical research budget of the National Institutes of Health (NIH), is Senator Richard Schweiker, Mr Reagan's running mate in his bid for the 1976 Republican nomination.

Mr Schweiker gave up his Senate seat earlier this year to work for Mr Reagan's election. In the Senate he was an active member of the Labor Committee's health and scientific research subcommittee, and as ranking minority member often supported the initiatives of the committee's present chairman, Senator Edward Kennedy.

$\mathrm{Mr}$ Schweiker is "definitely pro-science", one NIH official said last week, although adding that he had received some criticism for inserting in the institutes' funding legislation a clause that requires special arrangements for supporting research in diabetes and digestive diseases - the type of constraint that NIH prefers to work without.

The appointment would be less popular with labour unions, since Mr Schweiker is the sponsor of a bill designed to restrict the activities of the Occupational Safety and Health Administration.

As DHHS Secretary, Mr Schweiker would be responsible for the budget and activities of the National Institute of Occupational Safety and Health, part of the Center for Disease Control.

A predecessor in that post, Mr Caspar Weinberger, is widely tipped as next Secretary of Defense. He was director of the Office of Management and Budget under President Nixon, where his financial 